Final version: Carrero-Pazos, M., Bevan, A., Lake, M. 2019. The spatial structure of Galician megalithic landscapes (NW iberia): A case study from the Monte Penide region. Journal of Archaeological Science 108.

https://doi.org/10.1016/j.jas.2019.05.004

\title{
The Spatial Structure of Galician Megalithic Landscapes (NW Iberia): A Case Study from the Monte Penide Region
}

\section{Authors}

Miguel Carrero-Pazos. University of Santiago de Compostela.

miguel.carrero.pazos@gmail.com

Andrew Bevan. UCL Institute of Archaeology. a.bevan@ucl.ac.uk

Mark Lake. UCL Institute of Archaeology. mark.lake@ucl.ac.uk

\section{Introduction}

Megalithic tombs are a common social and funerary feature of Atlantic European landscapes during the Neolithic, involving the construction of large-scale stone monuments, typically but not exclusively collective graves covered by a mound (Laporte, Scarre 2011). Many explanations for the rise of megalithism and for the meaning of particular sets of megaliths have been offered by archaeologists in the past (Schultz Paulsson 2017), with an emphasis generally placed on their multiple rather than singular roles in society, and their likely symbolic marking of communally-shared resource landscapes belonging to segmentary groups (e.g. Saxe 1970; Fleming 1973; Chapman 1981; Tilley 1994; Sherratt 1990, 1995). Such investigations therefore highlight the importance of megalithic monuments not only as a funerary monuments but also as visible, public landmarks for living communities (Renfrew 1976; Renfrew 1984; Delibes de Castro 1991). Their potential territorial significance has been approached from different perspectives, including theoretical landscape archaeology (e.g. Criado Boado, Villoch Vázquez 2000; Criado Boado 2017), historical comparanda (e.g. Martinón-Torres 2001; Díaz Guardamino et al. 2015) and quantitative spatial analysis (e.g. Gillings 2009; Murrieta-Flores 2012, 2014; Llobera 2015).

One of the highest concentrations of megalithic monuments along the European Atlantic façade is Galicia (NW Iberian Peninsula), where there are more than ca.7,000 megalithic sites within an area of ca.30,000 sq.km (a density of 0.23/sq.km; Xunta de Galicia 2013). Certain smaller geographical regions offer yet denser megalithic landscapes, with A Costa da Morte boasting more than 500 sites in 1,740 sq.km (ca. 0.28/sq.km) or A Serra do Leboreiro's plateau in Portugal with more than 120 sites in 
Final version: Carrero-Pazos, M., Bevan, A., Lake, M. 2019. The spatial structure of Galician megalithic landscapes (NW iberia): A case study from the Monte Penide region. Journal of Archaeological Science 108. https://doi.org/10.1016/j.jas.2019.05.004

75 sq.km (1.6/sq.km; see Rodríguez Casal 1997; Eguileta Franco 1999; Ferreira de Sousa 2013; Vilas Estévez 2015; Carrero-Pazos 2018a).

The development of the Neolithic Period and the megalithic complex of northwest Iberia probably reflects funerary ideas that originally came from the centre of Portugal (Rodríguez Casal 1990; Prieto Martínez et al. 2012; Schultz Paulsson 2017). Although as yet constituting only a small number of finds, and in contrast to the pattern suggested elsewhere in Iberia, the existing archaeological evidence in the north-west suggests a degree of continuity between the latest Epipalaeolithic hunter-gatherers and the first food-producing communities, leading to the development a mixed economy during the first half of the 5th millennium BC. The earliest radiocarbon date associated with archaeological structures from this initial period is 4720-4530 BC (on an organic-rich sediment; Ua-3267, $5780 \pm 40$ uncal bp), and comes from a storage pit at Monte dos Remedios (Fábregas Valcarce et al. 2007; Prieto Martínez et al. 2012: 220). Additional available radiocarbon dates suggest, in general dates, the appearance of simpler singlechambered Galician megaliths over the period 4500-3500 BC, a subsequent development of corridor dolmens (3500-2500 BC) and then a late phase of megalithism (2500-1800 BC) characterised by small cists or burials without above-ground structures.

Despite a strong tradition of scientific study of these monuments by Galician and other researchers (see e.g. Criado Boado 1989; Bradley 1991a, 1991b, 1998), spatial approaches have until recently rarely extended beyond the creation of distribution maps (Leisner 1938; Rodríguez Casal 1997), accompanied by, often sensible but informallyexpressed, comments about locational factors such as those outlined in Table 1.

[Caption] Table 1. Variables of the locational model of the megalithic culture in Galicia as found in the literature (Carrero-Pazos 2017).

In the last few years, however, researchers have begun to adopt a more quantitative approach to the same observations via GIS and spatial modelling (Wheatley et al. 2010), although the emphasis has so far been on the relationship between sites and potential travel networks across the landscape (see e.g. Llobera 2015; Rodríguez Rellán, Fábregas Valcarce 2015; Carrero-Pazos 2018a; Carrero-Pazos, Rodríguez Casal in press). This growing body of work has identified a series of potentially relevant environmental 
Final version: Carrero-Pazos, M., Bevan, A., Lake, M. 2019. The spatial structure of Galician megalithic landscapes (NW iberia): A case study from the Monte Penide region. Journal of Archaeological Science 108. https://doi.org/10.1016/j.jas.2019.05.004

variables (such as topographic prominence or natural transit routes) that exhibit considerable statistical interdependence with one another (i.e. are highly correlated). Given this interdependence, many of these variables could, interpretatively, be seen as different ways of expressing the same general observation. In light of this, and after much wider exploration of the possibilities (Carrero-Pazos 2017) we have opted to consider just two of the simplest but most important variables - elevation and distance to major watershed boundaries (both variables were discussed by Bradley 1991a: 78; $1991 \mathrm{~b}$ in the case of south-west England burial mounds; by major watersheds here we generally mean those that have maritime outlets). This simpler starting point then allows us to conduct a more rigorous analysis and investigate both first and second-order patterns and site sizes (for the definition of these terms, see below and Bevan et al. 2013; Baddeley et al. 2016). We conclude that these Galician monuments made quite explicit use of the natural features of the landscape such as the ridgelines high up in major Galician upland watersheds which were both important transit routes for travel and major viewpoints. Moreover, we demonstrate that these monuments were organised into spatial clusters whose internal size hierarchies exhibited non-random structure suggesting some kind of organisational equivalence between clusters. These results can be independently reproduced with the data and analytical workflow provided in the accompanying repository (see Supplementary Data and Methods).

\section{Study area}

The study area is located in southern Galicia (NW Iberia, Figure 1) which was identified (on the basis of previous research by one of the authors: Carrero-Pazos 2017, $2018 \mathrm{~b}$ ) as a zone of 620 sq.km with one of the most important concentrations of megaliths in the whole Galician region. In this sub-region, 121 megalithic mounds are known, with important concentrations at Monte Penide, Monte Vixiador and As Pereiras. In what follows, we refer to this whole study region as 'Monte Penide and surroundings', in light of the fact that Monte Penide provides the densest concentration of sites.

[Caption] Figure 1. The study area in Galicia (NW Iberia), overlain on a shaded relief model. 
Final version: Carrero-Pazos, M., Bevan, A., Lake, M. 2019. The spatial structure of Galician megalithic landscapes (NW iberia): A case study from the Monte Penide region. Journal of Archaeological Science 108. https://doi.org/10.1016/j.jas.2019.05.004

In geographical terms, this is a comparatively flat region rising from the coast to moderate elevations (400-500 mASL). From a hydrological point of view, the watersheds of Verdugo and Oitavén rivers stand out, as well as the Miñor watershed which bounds the region to the south. Pico San Vicente (432 m) in Redondela, is the highest point in the north, and has one of the largest concentrations of mounds, such as that at Monte Penide. The main mountain range of the area is further to the East, the elongated (N-S direction) Serra do Galiñeiro (Coto de Cales, 742 m).

The megalithic monuments of these areas are well known in the literature: descriptive studies and early excavations were carried out by G. Álvarez Limeses (1935), C. de Mergelina (1936), P. Díaz Álvarez (1973), J. Filgueira Valverde and A. García Alén (1977), and J. M. Hidalgo Cuñarro and F. J. Costas Goberna (1979). Later, the excavations carried out by J. C. Abad Gallego in Cotogrande necropoleis (1990-1991; 1992-1993; 1995; 1996-1997) and Monte Penide provided very interesting case studies of the re-utilisation of these monuments through time. More recently, intensive survey by C. Gómez Nistal and A. Rodríguez Casal (2000), and then R. Fábregas Valcarce (2010, orig. 2001), updated the number of known barrows in the whole area. Nevertheless, despite a long history of research, the Galician megalithic phenomenon has only very recently been studied from a spatial perspective (Carrero-Pazos 2017, Figure 2).

[Caption] Figure 2. A: Current photograph from a megalithic mound in Monte Penide. B: Field plans of the excavations carried out by C. Mergelina (1936) in some of the monuments.

\section{Data and methods}

The archaeological data used in the analysis reported here is part of an archaeological database produced by the megalithic studies group at the University of Santiago de Compostela (GEPN-AAT). This group has catalogued 121 sites via both the accumulation of previous fieldwork (Carrero-Pazos 2017).

Site location analysis is one of the most prolific applications of GIS in archaeology over the last 35 years (early examples include: Kvamme 1983, 1984; Judge and Sebastian, 1988). Although these approaches have been criticised as encouraging undue 
Final version: Carrero-Pazos, M., Bevan, A., Lake, M. 2019. The spatial structure of Galician megalithic landscapes (NW iberia): A case study from the Monte Penide region. Journal of Archaeological Science 108. https://doi.org/10.1016/j.jas.2019.05.004

environmental determinism (Wheatley 1993, 1996, 2004; Gaffney, van Leusen 1995), they have nevertheless remained popular, especially when allied with modern spatial statistics which, via their ability to discriminate between first and second order effects (Bevan et al. 2013; Baddeley et al. 2016), potentially offer a more nuanced account of the balance between environmental and social causes of past human behaviour (see e. g. Williams 1993; Premo 2004; Bevan, Conolly 2006; Crema et al. 2010; Hinz 2011; Bevan 2012; Bevan et al 2013; Verhagen et al. 2013; Nakoinz, Knitter 2016). Previous work on Galician megaliths (Carrero-Pazos 2017, 2018b) developed a predictive model of megalithic site probability and assessed its effectiveness via a control sample, significance tests and a gain statistic (for the latter, Kvamme 1988). The conclusions from this wider exploratory exercise are summarised below in Table 2, which shows which covariates appeared to be better or worse predictors of the location of megalithic tombs in the study area.

[Caption] Table 2. Previous results from multivariate logistic regression (Carrero Pazos, 2017: 489).

Although previous work (Carrero Pazos 2017, 2018b) identified four covariates as important variables, an elevation cut-off is perhaps the most obvious one mentioned in previous discussion of megalithic monuments (Bradley 1991a: 78; 1991b). As noted above, here we deliberately retain a certain simplicity by investigating the role that just two major variables played in this megalithic area: elevation and distance to watershed edges (Figure 3: A, B), not least because these two are also likely to be useful proxies for other meaningful locational priorities such as ridge-routes and high visibility locations. We first conduct a univariate analysis of how the intensity of megalithic sites varies with respect to these two key variables and then build a multivariate logistic model which can account for the first-order spatial inhomogeneity in the megalithic sites, in other words, the overall spatial trend explained by properties of the environment. We then use this model as a control which allows us to identify the second-order properties of the site pattern, that is, those which may be more explicable in terms of social processes, such as what appears to be a tendency for a pre-existing mound to encourage the construction of nearby ones. 
Final version: Carrero-Pazos, M., Bevan, A., Lake, M. 2019. The spatial structure of Galician megalithic landscapes (NW iberia): A case study from the Monte Penide region. Journal of Archaeological Science 108. https://doi.org/10.1016/j.jas.2019.05.004

[Caption] Figure 3. A: watershed boundaries shown on top of an elevation model (the latter a first order covariate). B: a second covariate constructed by calculating the distance to watershed edges (excluding coastlines and with certain watersheds merged so that only basins with sea outlets remain). C: megalith site intensity as a function of terrain elevation. D: megalith site intensity as a function of watershed distance (solid lines show function estimate while grey shading is pointwise $95 \%$ confidence envelope). E: the predicted intensity of megalithic sites in the Monte Penide as constructed via logistic regression.

In the final part of the paper, we use the second-order results and a mark correlation function to suggest a meaningful clustering threshold with which to identify sub-groups of mounds using a dbscan method (Ester et al. 1996; as implemented in GRASS GIS v.cluster). Having identified these groups, we then use a novel rank permutation method to conclude that the tombs are distributed across them in a way that is that is broadly (even if not perfectly) hierarchical to an extent that is unlikely to occur by chance alone.

\section{First-Order Location Model}

The general distribution map of megalithic monuments documents a non-random distribution of sites over the study area (see figure 1) and we can use statistical methods to estimate the first-order trend behind much of this variation (Baddeley et al. 2016). First, it is useful to consider a non-parametric summary of the univariate relationships between the dependent variable (presence/absence of megalithic sites) and each of the two covariates (elevation and watershed edges, Figure 3C-D). These suggest that sites are more likely to occur at elevations ranging from 400-500 m ASL and at distances closer to watersheds than expected by chance alone. Comparison with previous work confirms that these two variables explain most of the overall variation even when further possible covariates are included (see Carrero-Pazos 2018a). We therefore build a first order logistic model using both covariates and produce a prediction surface of megalithic site intensity across the landscape. This model is then used in a second stage to study the clustering trend of the sites by fitting known statistical models to their spatial distribution (Figure 3E).

\section{Second-Order Clustering of Mounds}


Final version: Carrero-Pazos, M., Bevan, A., Lake, M. 2019. The spatial structure of Galician megalithic landscapes (NW iberia): A case study from the Monte Penide region. Journal of Archaeological Science 108. https://doi.org/10.1016/j.jas.2019.05.004

We have shown that elevation and watershed distance go some way towards explaining spatial patterning in the distribution of sites, but we can also investigate the possibility that there are additional - perhaps more overtly social - causes. We do this by using the logistic model of first order spatial inhomogeneity to detrend for the unevenness of megalithic sites due to landscape preferences, which then allows us to detect whether there is additional second-order clustering or regularity in the site point pattern across multiple scales (Baddeley et al. 2000: 330; Palmisano 2012; Baddeley et al. 2016). The inferential logic of this enquiry involves two main steps: first, we use a pair correlation function - which summarises the typical point intensity found in a series of noncumulative buffers around each point in the dataset - to identify second order clustering and construct a 95\% critical envelope for this function via random simulations conditioned on the first-order regression model (Baddeley et al. 2016: 225-230). We then consider whether the residual clustering can be explained with reference to one of the well-defined second order interaction models in the literature.

A basic pair correlation function confirms that the points are spatially clustered at distances up to $1 \mathrm{~km}$ (the black line remaining above the grey envelope in figure 4A-B). More precisely, the observed function (in black) falls above the Monte Carlo critical envelope at these short distances, before dropping back down within the expected range after this. A second version, in which the envelope is conditioned on the first order model (figure 4B), demonstrates that although first order trends are important, they do not account for the overall clustering (unless a major 'lurking' first-order variable has been ignored in both this and previous work, which we view as unlikely), and that the clustering is more likely to be endogenous and second-order in character (with the presence of one site making a nearby site more likely; see also Baddeley et al. 2016: 487). It is also interesting to note that megaliths possibly exhibit a slight dispersed pattern at distances of ca. 2000 meters (where the black line falls just beyond or at the lower limit of the grey envelope in figure 4A-B).

[Caption] Figure 4. Approaches to site distance and confidence. A: pair correlation function with a 95\% envelope from wholly random Poisson process. B: pair correlation function of the observed sites with a 95\% envelope conditioned on the first-order covariates model. C: pair correlation function with a 95\% envelope also conditioned on both the first-order covariates and a second-order, area-interaction model ( $\mathrm{r}=1500 \mathrm{~m})$. 
Final version: Carrero-Pazos, M., Bevan, A., Lake, M. 2019. The spatial structure of Galician megalithic landscapes (NW iberia): A case study from the Monte Penide region. Journal of Archaeological Science 108. https://doi.org/10.1016/j.jas.2019.05.004

Having identified clustering, we then fit a known point interaction model to the observed pattern. There are several Gibbs-type point processes that can be fitted: examples include a so-called hard core process, in which points strictly avoid each other up to a certain threshold, and a Strauss process in which points have constant influence within a certain distance threshold (Nakoinz, Knitter 2016: 131). However, in our case, the Widom-Rowlinson penetrable sphere model or area-interaction process (Baddeley, Lieshout 1995; Baddeley et al. 2016: 519) offers a better fit and more interpretative salience. This model generates inhibition and clustering patterns with reference to a buffer created for all the points of the distribution, which may be interpreted as modelling a scenario in which monuments have an area of influence within which they either attract or repel other monuments. Figure 4C shows that, after adding such a second-order interaction to our first-order model, the observed pair correlation function (black line) now falls within the critical envelope of the simulation at all interaction distances. This suggests that the jointly fitted first and second order factors are now able to account for the observed point pattern. In other words, the distribution of megalithic tombs can be accounted for by broad locational preferences for elevation and watershed boundaries, as described by the regression model in tandem with local tendencies towards mound clustering.

\section{Mound Size and Shape}

Given the observed second-order clustering of megalithic sites, it is interesting to further explore the nature of this clustering and what it might imply in terms of social organisation. If, for example, we use a mark correlation function to consider the spatial correlation of mound volumes (referred to hereafter as 'sizes'), there is evidence for significant auto-correlation of these sizes, not for mounds in very close proximity but rather for mounds spaced about 4.5km apart (Figure 5: A). Put very crudely, it would appear that whatever process dictates tomb size repeats at approximately $4.5 \mathrm{~km}$ intervals, which further implies that it might be possible to detect meaningful groups by clustering tombs using a distance to neighbour threshold of approximately half that size (2000 m). Figure 5B shows the result of using a dbscan method (Ester et al. 1996) to generate groups of sites using this threshold. 
Final version: Carrero-Pazos, M., Bevan, A., Lake, M. 2019. The spatial structure of Galician megalithic landscapes (NW iberia): A case study from the Monte Penide region. Journal of Archaeological Science 108.

https://doi.org/10.1016/j.jas.2019.05.004

[Caption] Figure 5. A: results of the mark correlation function for mound sizes/volumes. B: results of dbscan grouping analysis, showing possible groups of sites with a territorial meaning.

The resulting 9 clustered groups of mounds make visual sense, with groups concentrated by proximity. Thinking about possible social interpretations of these groups an obvious further question, given the mark correlation function results, is whether the mound sizes found within each group exhibit a non-random hierarchical distribution, in which each group contains at least one of the larger tombs, followed by a number of medium size tombs and finally a number of small tombs. For the sake of clarity, in this paper 'hierarchy' is understood as ranking, in the sense that our argument is about the distribution of tomb sizes characterised by their rank size. To our knowledge there is no existing technique available to assess the hierarchical nature distribution of tomb sizes given the uneven number of tombs with known sizes per group, so we introduce here a novel test based on permuting the rank order sizes of the tombs (for a complementary approach see Hennig and Lucianu 2000). The approach (see also the Supplementary Data and Methods) operates as follows: first, rank all tombs in descending order of size, so that the largest is ranked 1 and the smallest is ranked $n$, where $n$ is the number of tombs. Next, create a hierarchy of tomb-size ranks for each group, so that the biggest tomb in each group is placed in hierarchical level 1, the second biggest tomb in each group is placed in level 2, and so on. The result is a set of tomb-size ranks for each hierarchical level, which then allows us to compare the mean and/or sum of ranks at each hierarchical level with what we would get if we simply allocated tombs to size-levels with no reference to their group membership. For example, if the distribution of tombs across groups was perfectly hierarchical in the sense suggested above and there were, say, four groups of tombs, then the tomb-size ranks in level 1 should be 1, 2, 3 and 4, the ranks in level 2 should be 4, 5, 6 and 7, and so on, which is exactly what we would expect if we ignored group membership. Since, in reality, not all groups contain equal numbers of tombs, we adjust the expectation accordingly, i.e. the hierarchical levels will not have equal numbers of members. If we compare the observed ranks per level (i.e. those expected if a perfect size hierarchy pertained), we see (Table 3: IdealMeans) that the ideal mean ranks increase from one level to the next whereas that is not always true of the observed mean ranks. We also see that the level 1 and 2 ideal mean ranks are substantially numerically smaller (i.e. 
Final version: Carrero-Pazos, M., Bevan, A., Lake, M. 2019. The spatial structure of Galician megalithic landscapes (NW iberia): A case study from the Monte Penide region. Journal of Archaeological Science 108. https://doi.org/10.1016/j.jas.2019.05.004

higher ranking in descending order of size) than their observed equivalents. The conclusion that can be drawn from this is that the observed allocation of tomb sizes across groups is not perfectly hierarchical, but it may nevertheless be closer to such an idealised hierarchical distribution than we might expect by chance. We can examine this possibility by conducting a Monte Carlo significance test (Hope 1968) to establish how frequently the observed mean rank at a given level in the hierarchy is numerically lower (i.e. higher ranking) than the equivalent mean ranks obtained in a large number of simulations in which tomb sizes are allocated independently of group membership. This entails repeatedly permuting (randomly shuffling the tomb sizes) and re-running the allocation of ranks to levels by group. We conduct 999 such simulations and then in accordance with standard practice (Manly 1991) derive p-values by comparing the extremeness of the observed mean ranks at a given hierarchical level to the simulated mean ranks at that level (Table 3: Pval). Note that we have not attempted to compute a p-value for the distribution of ranks across all hierarchical levels as it is a moot point whether the latter would constitute the testing of multiple hypotheses and so require correction of the p-values to control the family-wise error rate (Holm 1979). The result of this Monte Carlo simulation suggests that the observed distribution of tomb sizes in each of the first two hierarchical levels is closer to that expected of a hierarchical distribution (each group having a tomb ranked highly by size) than would be expected by chance (i.e. $p<=0.05$ ). In fact, this is true for three out of the first four hierarchical levels. Consequently, our test supports the argument that the largest tombs are distributed across the groups in a way that is broadly (albeit not perfectly) hierarchical, to an extent that is unlikely to occur by chance alone.

[Caption] Table 3. Results of the permutation tests on megalithic site sizes by cluster group.

\section{Discussion}

Modern spatial statistical methods allow us to move beyond a now rather stale debate about environmental determinism, because they facilitate empirical investigation of the interplay of different causes, as opposed to the a priori assertion of primacy according to theoretical preference. In this case, we have been able to demonstrate that distribution of megalithic mounds in the Monte Penide region reflects a preference for 
Final version: Carrero-Pazos, M., Bevan, A., Lake, M. 2019. The spatial structure of Galician megalithic landscapes (NW iberia): A case study from the Monte Penide region. Journal of Archaeological Science 108. https://doi.org/10.1016/j.jas.2019.05.004

locations with particular environmental properties, but at a more local scale the spacing of these mounds seems to reflect some kind of social partitioning of the landscape.

The results described above allow us to conclude that megalithic sites in the Monte Penide region concentrate at specific elevations (300-500 mASL) close to the ridgelines that define the main watersheds draining to the sea. Once these major locational trends are accounted for, sites still exhibit clustering within $1 \mathrm{~km}$ of each other, probably implying that once some megalithic landmarks were established, these encouraged the construction of new ones nearby. These patterns elicit interesting archaeological interpretations. First, they suggest that different groups in the regions gradually built up mound groups on the upland side of possible local territories (see also Bakker 1976, 1991; Bradley 1991a; Criado Boado, Villoch Vázquez 2000; Murrieta-Flores 2012), on ridge tops draining to the sea. These locations also placed such mounds in highly visible locations on major routes of upland travel across the landscape (see also Carrero-Pazos 2018b), but we make no attempt here to tease apart which of these motivations, if any, might have been the most important one for the mound-builders.

Beyond the broader locational preferences, the distribution of mound volumes/sizes in the nine identified clusters exhibit a non-random hierarchical pattern, with a larger mound per group and then smaller ones around that, with what appears to be a preference for the large example to be at or near the meeting point of several watersheds (and upland ridge-routes). At risk of straying too far beyond the evidence, this observation suggests that the Monte Penide region was probably occupied by several groups of roughly equivalent status. Furthermore, without wishing to delineate strict territories without better dating and wider evidence, it is still a useful thought experiment to imagine rough zones of activity that often gave each of these identified groups a strip of land from mountain to sea of ca.70 sq.km, and larger still if such areas also extended over into the inland valleys.

Such conclusions fairly match with the spatial structure of megalithic landscapes in other Iberian and European regions, such as for example in Falbygden, Sweden (Sjögren 2010) where mounds tend to be found in marginal zones and in clusters, with a large tomb in the centre of the area. In that case, the interpretation was that such patterning related to social factors, such as the organisation of settlement or social 
Final version: Carrero-Pazos, M., Bevan, A., Lake, M. 2019. The spatial structure of Galician megalithic landscapes (NW iberia): A case study from the Monte Penide region. Journal of Archaeological Science 108. https://doi.org/10.1016/j.jas.2019.05.004

groups, with mounds acting as territorial markers. Similarly, the role of megalithic architectures as landmarks, waypoints or territorial markers that have helped to structure movement along emerging path networks has been very well analysed in south-Iberian megaliths (Wheatley et al. 2010). On the other hand, linear arrangements of barrows in the Netherlands and Ukraine have been interpreted as being the result of processes of extension through time, probably representing lineages or family necropolis (a trend especially visible in the Bronze Age, e.g. Bourgeois 2013; Makarowicz et al. 2018). Furthermore, differences in tomb orientation may in certain circumstances indicate specific cultural or funerary trends (Hoskin 2001; Silva 2010; Prendergast 2016), but this is still under initial investigation in Galicia (see e.g. Corujo-Tilve, Domínguez Márquez 2014; González García et al. 2017; 2018).

Future work in Galicia would clearly benefit from better radiocarbon dating of mound use-lives and mound groups, and some efforts in this direction are already underway in the Barbanza peninsula, west of Galicia (Rodríguez Rellán, Fábregas Valcarce in press) in order to elucidate a better 'biography' of megalithic sequences (Rodríguez Casal 1989; Alonso Mathías, Bello Diéguez 1995; Mañana Borrazás 2005; Bóveda Fernández, Vilaseco Vázquez 2015). Likewise, there is much still to infer about what the possible territories really mean in terms of anticipated community sizes and social structure, something more visible in later periods such as the Bronze Age. However the above exploration already suggests new theory and method that might be applied to a much wider set of Galician and European megalithic evidence.

\section{Acknowledgements}

The archaeological dataset used in this work was kindly provided by Prof. Antón A. Rodríguez Casal from the University of Santiago de Compostela, as a part of the project "Archaeology and Ecology of the Megalithic Complex in the South of Galicia" (19982000), funded by the regional government of Galicia (Xunta de Galicia). The digital elevation model (LiDAR based) was obtained from the Spanish National Cartographic Service (http://centrodedescargas.cnig.es/CentroDescargas/index.jsp), derived from DTM25 CC BY 4.0 https://www.ign.es/. We used GRASS GIS 7.4 (GRASS Development Team 2015) and the $\mathrm{R}$ statistical environment for all the analysis ( $\mathrm{R}$ Development Core Team 2008, especially the spatstat package, Baddeley et al. 2016). A first draft version of this paper (poster) was presented in the International Colloquium 
Final version: Carrero-Pazos, M., Bevan, A., Lake, M. 2019. The spatial structure of Galician megalithic landscapes (NW iberia): A case study from the Monte Penide region. Journal of Archaeological Science 108. https://doi.org/10.1016/j.jas.2019.05.004

on Digital Archaeology: Quantitative approaches, spatial statistics and socioecological modelling, University of Bern, Oeschger Centre for Climate Change Research, Bern (04/02/2019-06/02/2019). Our thanks also to the reviewers and the editor for their helpful and useful comments.

\section{Supplementary Data and Methods}

To enable re-use of our materials and improve reproducibility and transparency, we include the raw data and $\mathrm{R}$ code used for all the analysis and visualisations contained in this paper in our supplemental online material at (http://dx.doi.org/10.17632/3sb4hwrrw9.1). The data used in this paper is released under the CC-BY4.0 license and our code with the MIT license to encourage maximum reuse.

\section{References}

Abad Gallego, J. C. (1990-1991). La excavación de la mámoa n² de Cotogrande (Cabral-Vigo). Castrelos 3-4: 29-43.

Abad Gallego, J. C. (1992-1993). Balance de las actuaciones arqueológicas llevadas a cabo en la necrópolis megalítica de Cotogrande (Cabral). Castrelos 5-6: 7-28.

Abad Gallego, J. C. (1995). Un ejemplo de readaptaciones constructivas en un enterramiento tumular: Cotogrande n ${ }^{\circ}$. Minius IV: 13-30.

Abad Gallego, J. C. (1996-1997). Materiales líticos procedentes de la necrópolis megalítica de Monte Penide (Redondela). Castrelos 9-10: 11-16.

Alonso Mathías, F., Bello Diéguez, J. (1995). Aportaciones del monumento de Dombate al megalitismo noroccidental: dataciones de Carbono 14 y su contexto arqueológico. Trabalhos de Antropologia e Etnologia 35 (3): 153-181.

Álvarez Limeses, G. (1935). Geografía del Reino de Galicia. Tomo de la Provincia de Pontevedra. Barcelona: Casa Editorial Alberto Martin.

Baddeley, A., Van Lieshout, M. N. M. (1995). Area-Interaction point processes. Annals of the Institute of Statistical Mathematics, 47: 601-619. 
Final version: Carrero-Pazos, M., Bevan, A., Lake, M. 2019. The spatial structure of Galician megalithic landscapes (NW iberia): A case study from the Monte Penide region. Journal of Archaeological Science 108. https://doi.org/10.1016/j.jas.2019.05.004

Baddeley, A., Moller, J., Waagepetersen, R. (2000). Non-and semi-parametric estimation of interaction in inhomogeneous point patterns. Statistica Neerlandica 54: 329-350.

Baddeley, A., Rubak, E., Turner, R. (2016). Spatial Point Patterns: Methodology and Applications with R. London: CRC Press.

Baddeley, A., Turner, R. (2005). Modelling Spatial Point Patterns in R. In Baddeley, A., Gregori, P., Mateu, J., Stoica, R., Stoyan, D. Case Studies in Spatial Point Process Modeling (pp. 23-74). New York: Springer.

Bakker, J. A. (1976). On the Possibility of Reconstructing Roads from the TRB Period. Berichten van de Rijksdienst voor het Oudheidkundig Bodemonderzoek 26: 63-91.

Bakker, J. A. (1991). Prehistoric Long-Distance Roads in North-West Europe. In Lichardus, J. (Ed.). Die Kupferzeit als historische Epoche. Symposium Saarbrücken und Otzenhausen 6-13, November 1988. Bonn: Dr Rudolf Habelt GmbH: 505-528.

Bello Diéguez, J. M. (1995). Arquitectura, arte parietal y manifestaciones escultóricas en el Megalitismo noroccidental. In Losada, F., Castro Pérez, L. (Eds), Arqueoloxía e arte na Galicia prehistórica e romana (pp. 29-98). Coruña: Museo Arqueolóxico e Histórico de A Coruña.

Bello Diéguez, J. M. , Criado Boado, F., Vázquez Varela, J. M. (1982a). Aproximación a un modelo económico-social del megalitismo del noroeste peninsular. Brigantium, 3: 33-39.

Bello Diéguez, J. M. a, Criado Boado, F., Vázquez Varela, J. M. (1982b). Sobre la cultura megalítica y los caminos antiguos en Galicia. El Museo de Pontevedra, 26: 143164.

Bello Diéguez, J. M. , Criado Boado, F., Vázquez Varela, J. M. (1982c). Megalitismo y medio físico en el Noroeste de la Península Ibérica: Estado de la cuestión y perspectivas. Zephyrus, XXXIV-XXXV: 109-118.

Bello Diéguez, J. M. a, Criado Boado, F., Vázquez Varela, J. M. (1984). Medio físico y sociedades megalíticas: aproximación a los problemas constructivos de los megalitos en el NW peninsular. Gallaecia, 7-8: 31-57. 
Final version: Carrero-Pazos, M., Bevan, A., Lake, M. 2019. The spatial structure of Galician megalithic landscapes (NW iberia): A case study from the Monte Penide region. Journal of Archaeological Science 108. https://doi.org/10.1016/j.jas.2019.05.004

Bello Diéguez, J. M.a , Criado Boado, F., Vázquez Varela, J. M. (1987). La cultura megalítica de la provincia de la Coruña y sus relaciones con el marco natural: implicaciones socio-económicas. A Coruña: Excma. Diputación provincial de A Coruña.

Bevan, A., Conolly, J. (2006). Multiscalar approaches to settlement pattern analysis. In G. Lock, Molyneaux, B. (Eds.), Confronting scale in archaeology: issues of theory and practice (pp. 217-234). New York: Springer.

Bevan, A. (2012). Spatial methods for analysing large-scale artefact inventories. Antiquity 86 (443): 493-506.

Bevan, A., Crema, E., Li, X. and A. Palmisano (2013). Intensities, interactions and uncertainties: some new approaches to archaeological distributions. In: Bevan, A. and M. Lake (eds.) Computational Approaches to Archaeological Spaces (pp. 2752). Walnut Creek: Left Coast Press.

Bóveda Fernández, M. ${ }^{a}$ J., Vilaseco Vázquez, X. I. (2015). La cámara megalítica de Chousa Nova 1 (Silleda, Pontevedra). ¿Rotura intencional o colapso? In Gonçalves, V. S., Diniz, M., Sousa, A. C. (Eds.), Actas do $5^{\circ}$ Congreso do Neolítico Peninsular. Faculdade de Letras da Universidade de Lisboa, 7-9 abril 2011 (pp. 564-570). Lisboa: UNIARQ WAPS.

Bourgeois, Q. (2013). Monuments on the Horizon. The formation of the barrow landscape throughout the $3^{\text {rd }}$ and $2^{\text {nd }}$ millennium BC. Leiden: Sidestone Press.

Bradley, R. (1991a). Rock art and the perception of landscape. Cambridge Archaeological Journal, 1: 77-101.

Bradley, R. (1991b). Monuments and places. In Garwood, P., Jennings, D., Skeates, R., Thoms, J. Sacred and Profane. Oxford: Oxford University Committee for Archaeology.

Bradley, R. (1998). The significance of monuments. On the shaping of human experience in Neolithic and bronze age Europe. London: Routledge.

Carrero-Pazos, M. (2015). Sobre geografía y espacio funerario megalítico en Galicia. Aproximación a su interpretación. In E. Ramil Rego (Ed.), 3 Congreso Internacional de Arqueoloxía de Vilalba (Vilalba, 2015) (Férvedes 8) (pp. 153-161). Vilalba: Museo de Prehistoria e Arqueoloxía de Vilalba. 
Final version: Carrero-Pazos, M., Bevan, A., Lake, M. 2019. The spatial structure of Galician megalithic landscapes (NW iberia): A case study from the Monte Penide region. Journal of Archaeological Science 108. https://doi.org/10.1016/j.jas.2019.05.004

Carrero-Pazos, M. (2017). The Megalithic Phenomenon in Galicia. Contributions from Geographic Information Systems and Spatial Statistics to the Study of Site Location Patterns. PhD Research. University of Santiago de Compostela. Santiago de Compostela. http://hdl.handle.net/10347/15823

Carrero-Pazos, M. (2018a). Beyond the scale. Building formal approaches for the study of spatial patterns in Galician moundscapes (NW Iberian Peninsula). Journal of Archaeological Science: Reports, 19: 538-551.

Carrero-Pazos, M. (2018b). Modelando dinámicas de movilidad y visibilidad en los paisajes megalíticos gallegos. El caso del Monte de Santa Mariña y su entorno (Comarca de Sarria, Lugo). Trabajos de Prehistoria. 75 (2): 287-306. DOI: https://doi.org/10.3989/tp.2018.12216

Carrero-Pazos, M. (2019). Density, intensity and clustering patterns in the spatial distribution of Galician megaliths (NW Iberian Peninsula). Archaeol Anthropol Sci. 11, 5: 2097-2108. https://doi.org/10.1007/s12520-018-0662-2

Carrero-Pazos, M., Rodríguez Casal, A. A. (in press). General and local spatial trends in Galician megalithic landscapes. In Hinz, M., Müller, J. Megaliths, societies and landscapes. Early monumentality and social differentiation in Neolithic Europe. Bonn: Habelt.

Castillo López, Á. d. (1927). Un depósito de hachas del bronce de talón. Boletín de la Real academia Galega, 17 (194): 33-42.

Chapman, R. (1981). Archaeological theory and communal burial in prehistoric Europe. In I. Hodder, Isaac, G., Hammond, N. (Eds.), Pattern to process. Studies in honour of David Clarke (pp. 387-412). Cambridge: Cambridge University Press.

Corujo-Tilve, J. P., Domínguez-Márquez, M. T. (2014). "Islas de luz", el factor de localización de las necrópolis tumulares en el Suroeste de Galicia. Gallaecia 33, 59-96.

Crema, E., Bevan, A., Lake, M. (2010). A probabilistic framework for assessing spatiotemporal point patterns in the archaeological record. Journal of Archaeological Science 37(5): 1118-1130. 
Final version: Carrero-Pazos, M., Bevan, A., Lake, M. 2019. The spatial structure of Galician megalithic landscapes (NW iberia): A case study from the Monte Penide region. Journal of Archaeological Science 108. https://doi.org/10.1016/j.jas.2019.05.004

Criado Boado, F. (1988). Contribución al estudio de las relaciones entre las comunidades megalíticas del noroeste peninsular y su medio natural: implicaciones socio-económicas. Santiago de Compostela. Universidade de Santiago de Compostela.

Criado Boado, F. (1989). Megalitos, Espacio, Pensamiento. Trabajos de Prehistoria, 46: $75-98$.

Criado Boado, F. (2017). A paisaxe como enxeñería inversa da materia e a memoria. In VVAA. Paisaxe e Patrimonio - Un percorrido polo territorio a través do Arquivo de Galicia. Santiago de Compostela: Xunta de Galicia. Consellería de Cultura, Educación e Ordenación Universitaria, pp. 149-157.

Criado Boado, F., Grajal Blanco, M. (1981). Relación entre la distribución de mámoas y el medio físico de la zona de Sobrado-Curtis. Brigantium, 2, 7-26.

Criado Boado, F., Vaquero Lastres, J. (1991). El fenómeno megalítico y tumular: formas diversas de pasado monumental. In F. Criado Boado (Ed.), Arqueología del paisaje. El área Bocelo-Furelos entre los tiempos paleolíticos y medievales (Vol. Arqueoloxía/Investigación: 6, pp. 129-146). A Coruña: Xunta de Galicia.

Criado Boado, F., Villoch Vázquez, V. (2000). Monumentalizing landscape: from present perception to the past meaning of Galician Megalithism (north-west Iberian Peninsula). European Journal of Archaeology, 3 (2): 188-216.

Delibes de Castro, G. (1991). Megalitos ¿Todavía una civilización de muertos? Arqrítica. Crítica de Arqueología Española, 2 (2): 9-10.

Díaz Álvarez, P. (1973). Noticias de prehistoria en torno a Vigo y su ría. Vigo: Caja de Ahorros Municipal de Vigo.

Díaz Guardamino, M., García Sanjuán, L., Wheatey, D. (2015). The Lives of Prehistoric Monuments in Iron Age, Roman, and Medieval Europe. Oxford: Oxford University Press.

Díaz Sanjurjo, M. (1904). Los caminos antiguos y el itinerario $\mathrm{n}^{\circ} 18$ de Antonino en la provincia de Orense. Boletín de la Comisión de Monumentos Históricos y Artísticos de Orense II: $37-43$.

Eguileta Franco, J. Ma . (1999). A Baixa Limia na Prehistoria Recente. Arqueoloxía dunha Paisaxe na Galicia interior. Ourense: Excma. Diputación Provincial de Ourense. 
Final version: Carrero-Pazos, M., Bevan, A., Lake, M. 2019. The spatial structure of Galician megalithic landscapes (NW iberia): A case study from the Monte Penide region. Journal of Archaeological Science 108. https://doi.org/10.1016/j.jas.2019.05.004

Ester, M., H.-P. Kriegel, J. Sander, and X. Xu (1996). "A Density-Based Algorithm for Discovering Clusters in Large Spatial Databases with Noise". In: Proceedings of $2^{\text {nd }}$ International Conference on Knowledge Discovery and Data Mining (KDD-96). Ed. By Simoudis, E., J. Han, and U.M. Fayyad. Portland: AAAI Press, pp. 226-231.

Fábregas Valcarce, R. (2010). Os petróglifos e o seu contexto. Vigo: Instituto de Estudios Vigueses.

Fábregas Valcarce, R., Bonilla Rodríguez, A., César Vila, M. (2007). Monte dos Remedios (Moaña, Pontevedra): un asentamiento de la Prehistoria reciente. Santiago de Compostela: Tórculo.

Ferreira de Sousa, M. G. (2013). O fenómeno tumular e megalítico na região galaicoportuguesa do Minho. Santiago de Compostela: Tese doutoral. Universidade de Santiago de Compostela.

Filgueira Valverde, J., García Alén, A. (1977). Inventario de monumentos megalíticos de la provincia de Pontevedra. El Museo de Pontevedra 31: 43-130.

Filgueiras Rey, A. I., Rodríguez Fernández, T. (1994). Túmulos y petroglifos. La construcción de un espacio funerario. Aproximación a sus implicaciones simbólicas. Estudio en la Galicia centro-oriental: Samos y Sarria. Espacio, Tiempo y Forma, Serie I, Prehistoria y Arqueología, 7: 211-253.

Fleming, A. (1973). Tombs for the living. Man, 8 (2): 177-193.

Gaffney, V., Van Leusen, P. M. (1995). Postscript: GIS, environmental determinism and archaeology. A parallel text. En G. Lock, Stancic, Z. (Eds.), Archaeology and Geographical Information System: A European Perspective (pp. 367-382). London: Taylor and Francis.

Gillings, M. (2009). Visual Affordance, Landscape, and the Megaliths of Alderney. Oxford Journal of Archaeology, 28: 335-356.

Gómez Nistal, C., Rodríguez Casal, A. A. (2000). El fenómeno tumular y megalítico en la Galicia suroccidental: aspectos historiográficos y estado actual de la investigación. In V. O. Jorge (Ed.), Congresso de Arqueologia Peninsular (3 . 2000, Vila Real)Neolitizaçao e Megalitismo na Peninsula Iberica (pp. 321-336). Porto: ADECAP. 
Final version: Carrero-Pazos, M., Bevan, A., Lake, M. 2019. The spatial structure of Galician megalithic landscapes (NW iberia): A case study from the Monte Penide region. Journal of Archaeological Science 108. https://doi.org/10.1016/j.jas.2019.05.004

Gómez Vila, J. (2005). Caminos y túmulos: aproximación al estudio de los caminos megalíticos en el noroeste peninsular. En P. Arias Cabal, Ontañón Peredo, R., García Moncó, C. (Eds.), Actas del III Congreso del Neolítico en la Península Ibérica (Santander, 2003) (pp. 405-412). Santander: Universidad de Cantabria.

González García, C., Criado-Boado, F., Vilas Estévez, B. (2017). Megalithic skyscapes in Galicia. Culture and Cosmos 21: 87-103.

González García, C., Vilas Estévez, B., López Romero, E., Mañana Borrazás, P. (2019). Domesticating Light and Shadows in the Neolithic: The Dombate Passage Grave (A Coruña, Spain). Cambridge Archaeological Journal 29 (2): 327-343.

GRASS Development Team (2015). Geographic Resources Analysis Support System (GRASS) Software, Version 7.0.2. Open Source Geospatial Foundation. Electronic document: http://grass.osgeo.orgHidalgo Cuñarro, J. M., Costas Goberna, F. J. (1979). El Gran conjunto megalítico de Monte Penide. Redondela-Pontevedra. El Museo de Pontevedra, 34: 1-93.

Hennig, v. H., Lucianu, C. (2000). Zipf, Christaller, Gräberfelder. Sind latent besieldlungsstrukturen der hallstattzeit aus der verteilung der nekropolen ersichtlich? Archäologisches Korrespondenblatt 4: 527-548.

Hinz, M. (2011). Who for Whom? Ritual Architecture in the Light of the related Population. In Furholt, M., Müller, J., Lüth, F. (Eds.), Megaliths and identities: early monuments in Neolithic societies from the Atlantic to the Baltic; 3rd European Megalithic Studies Group meeting 13th - 15th of May 2010 at Kiel University (pp. 129142). Habelt: Bonn.

Holm, S. (1979). A simple sequentially rejective multiple test procedure. Scandinavian Journal of Statistics 6 (2): 65-70.

Hope, A.C.A. (1968). A simplified Monte Carlo significance test proedure. Journal of the Royal Statistical Society B30: 582-598.

Hoskin, M. (2001). Tombs, temples and their orientations. Ocarina Books: Bognor Regis. 
Final version: Carrero-Pazos, M., Bevan, A., Lake, M. 2019. The spatial structure of Galician megalithic landscapes (NW iberia): A case study from the Monte Penide region. Journal of Archaeological Science 108. https://doi.org/10.1016/j.jas.2019.05.004

Judge, J. W., Sebastian, L. (Eds) (1988). Quantifying the present and predicting the past: theory, method and application of archaeological predictive modelling. Denver: U.S. Department of the Interior, Bureau of Land Management.

Kvamme, K.L. (1983). A manual for predictive site location models: examples from the Grand Junction District, Colorado. Grand Junction: District Bureau of Land Management.

Kvamme, K.L. (1984). Models of prehistoric site location near Pinyon Canyon, Colorado. In: Condie, C. J. (Ed), Papers of the Philmont conference on the archaeology of northeastern New Mexico (pp. 349-370). New Mexico: Archaeological Council, Albuquerque.

Kvamme, K.L. (1988). Development and testing of quantitative models, In W.J. Judge and L. Sebastian (eds.) Quantifying the Present and Predicting the Past: Theory, Method, and Application of Archaeological Predictive Modeling: 325-428. Denver: U.S. Department of the Interior, Bureau of Land Management.

Laporte, L., Scarre, C. (2011). The Megalithic Architectures of Europe. Oxford: Oxbow Books.

Leisner, G. (1938). Verbreitung und Typologie der Galizisch-Nordportugiesischen Megalithgräber. München: J. B. Lindin.

López Cuevillas, F. (1925). As mámoas do Concello de Lobeira. Boletín de la Real Academia Gallega, XV: 25-39.

López Cuevillas, F. (1959). La época megalítica en el Noroeste de la Península. Caesaraugusta, 13-14: 21-77.

Llobera, M. (2015). Working the Digital: Some thoughts from Landscape Archaeology. In R. Chapman, Wylie, A. (Eds.), Material Evidence: Learning from Archaeological Practice (pp. 173-188). Abingdon: Routledge.

Maciñeira, F. (1943-1944). Túmulos prehistóricos. Inventario descriptivo de los 286 túmulos prehistóricos hasta ahora descubiertos en la avanzada comarca del cabo Ortegal. Boletín de la Real Academia Gallega, 23-24: 15-34.

Makarowicz, P., Goslar, T., Niebieszczańskia, J., Cwalińskia, M., Kochkind, I. T., Romaniszyna, J., Lysenkoe, S. D., Ważnyf, T. (2018). Middle Bronze Age societies and 
Final version: Carrero-Pazos, M., Bevan, A., Lake, M. 2019. The spatial structure of Galician megalithic landscapes (NW iberia): A case study from the Monte Penide region. Journal of Archaeological Science 108. https://doi.org/10.1016/j.jas.2019.05.004

barrow line chronology. A case study from the Bukivna 'necropolis', Upper Dniester Basin, Ukraine. Journal of Archaeological Science, 95: 40-51.

Mañana Borrazás, P. (2005). Túmulo 5 de Forno dos Mouros (Ortigueira, A Coruña). Primeiros resultados. Cuadernos de Estudios Gallegos LII, 118: 39-79.

Manly, B.F.J. (1991). Randomization and Monte Carlo Methods in Biology. London: Chapman and Hall.

Martinón-Torres, M. (2001). Os monumentos megalíticos despois do Megalitismo. Arqueoloxía e Historia dos megalitos a través das fontes escritas (S. VI-S. XIX). Valga: Concello de Valga.

Méndez Fernández, F. (1998). Definición y análisis de poblados de la Edad del Bronce en Galicia. In R. Fábregas Valcarce (Ed.), A Idade do Bronce en Galicia: novas perspectivas (Vol. 77, pp. 153-190). A Coruña: Cadernos do Seminario de Sargadelos.

Mergelina, C.D. (1936). Notas sobre arqueología gallega. Las mámoas del Chan da Pedra do Couto y de San Colmado. Boletín del Seminario de Estudios de Arte y Arqueología de Valladolid, 10: 1-33.

Murrieta-Flores, P. (2012). Understanding human movement through spatial technologies: the role of natural areas of transit in the Late Prehistory of South-western Iberia. Trabajos de Prehistoria, 69 (1): 103-122.

Murrieta-Flores, P. (2014). Developing computational approaches for the study of movement: assessing the role of visibility and landscape markers in terrestrial navigation during Iberian Late Prehistory. In S. Polla and P. Verhagen (Eds.), Computational Approaches to the Study of Movement in Archaeology Theory, Practice and Interpretation of Factors and Effects of Long Term Landscape Formation and Transformation (pp. 99-132). Berlin: De Gruyter.

Nakoinz, O., Knitter, D. (2016). Modelling Human Behaviour in Landscapes. Basic Concepts and Modelling Elements. Springer: Switzerland.

Palmisano, A. (2012). Zooming patterns among the scales: a statistic technique to detect spatial patterns among settlements. In G. Earl, Sly, T., Chrisanty, A., Murrieta Flores, P., Papadopoulos, C., Romanowska, I., Wheatley, D. (Eds.), Archaeology in the Digital Era (pp. 348-356). Southampton: CAA Proceedings. 
Final version: Carrero-Pazos, M., Bevan, A., Lake, M. 2019. The spatial structure of Galician megalithic landscapes (NW iberia): A case study from the Monte Penide region. Journal of Archaeological Science 108. https://doi.org/10.1016/j.jas.2019.05.004

Premo, L. (2004). Local spatial autocorrelation statistics quantify multi-scale patterns in distributional data: an example from the Maya Lowlands. Journal of Archaeological Science 31: 855-866.

Prieto Martínez, P., Mañana Borrazás, P., Costas Casais, M., Criado Boado, F., López Sáez, J. A., Carrión Marco, Y., Martínez Cortizas, A. (2012). Galicia. In M. A. Rojo Guerra, Garrido Pena, R., García Martínez de Lagrán, Í. (Eds.), El Neolítico en la Península Ibérica y su contexto europeo (pp. 215-253). Madrid: Cátedra.

R Development Core Team (2008). R: A language and environment for statistical computing. R Foundation for Statistical Computing, Vienna, Austria. ISBN 3-90005107-0, URL http://www.R-project.org.

Renfrew, C. (1976). Megaliths, Territories and Populations. In S.J. De Laet (Ed.), Acculturation and Continuity in Atlantic Europe, Mainly During the Neolithic period and the Bronze Age (pp. 198-220). Brugge: De Tempel.

Renfrew, C. (1984). Arqueología social de los monumentos megalíticos. Investigación y Ciencia, 88: 70-79.

Rodríguez Casal, A. (1989). La necrópolis megalítica de Parxubeira. A Coruña: Monografías urxentes do Museu de San Antón, nº 4. Museu Arqueolóxico e histórico de San Antón.

Rodríguez Casal, A. A. (1997). O Neolítico atlántico e as orixes do Megalitismo: actas do Coloquio Internacional (Santiago de Compostela, abril de 1996). Santiago de Compostela: Universidade de Santiago de Compostela.

Rodríguez Rellán, C., Fábregas Valcarce, R. (2015). Arte rupestre galaica: unha achega dende a estatística espacial e os SIX. In A. A. Rodríguez Casal, Blanco Chao, R., Sistemas de Información Geográfica, gestión del territorio y conocimiento histórico (Sémata, Ciencias Sociais e Humanidades, 27) (pp. 323-348). Santiago de Compostela: Universidade de Santiago de Compostela.

Rodríguez Rellán, C., Fábregas Valcarce, R. (in press). Monuments on the move. Assessing megalith's interaction with NW Iberian landscapes. In Hinz, M., Müller, J. Megaliths, societies and landscapes. Early monumentality and social differentiation in Neolithic Europe. Bonn: Habelt. 
Final version: Carrero-Pazos, M., Bevan, A., Lake, M. 2019. The spatial structure of Galician megalithic landscapes (NW iberia): A case study from the Monte Penide region. Journal of Archaeological Science 108. https://doi.org/10.1016/j.jas.2019.05.004

Santos Estévez, M. (2008). Petroglifos y paisaje social en la prehistoria reciente del noroeste de la Península Ibérica (TAPA, Vol. 38). Santiago de Compostela: Instituto de Estudos Galego Padre Sarmiento. CSIC.

Santos Estévez, M., Parcero Oubiña, C., Criado Boado, F. (1997). De la arqueología simbólica del paisaje a la arqueología de los paisajes sagrados. Trabajos de Prehistoria, 54 (2): 61-80.

Saxe, A. A. (1970). Social dimensions of mortuary practices. Michigan: University of Michigan.

Schultz Paulsson, B. (2017). Time and Stone: The Emergence and Development of Megaliths and Megalithic Societies in Europe. Oxford: Archaeopress.

Sherratt, A. (1990). The genesis of megaliths: monumentality, ethnicity and social complexity in Neolithic North-West Europe. World Archaeology, Soils and Early Agriculture, 22 (2): 147-167.

Sherratt, A. (1995). Instruments of Conversion? The Role of Megaliths in the Mesolithic/Neolithic Transition in Northwest Europe. Oxford Journal of Archaeology, 14: $245-260$.

Silva, F. (2010). Cosmology and the Neolithic: A New Survey of Neolithic Dolmens in Central Portugal. Journal of Cosmology 9, 3094-3106.

Sjögren, K. G. (2010). Megaliths, landscapes and identities: the case of Falbygden, Sweden. In Furholt, M., Lüth, F., Müller, J. (Eds.). Megaliths and identities. Early Monuments and Neolithic Societies from the Atlantic to the Baltic (pp. 155-166). Habelt, Bonn.

Tilley, C. (1994). A phenomenology of Landscape. Paths, Places and Monuments. Oxford: Berg.

Vaquero Lastres, J. (1990). Ríos y tumbas. Sobre el emplazamiento de túmulos en el NW peninsular. Trabalhos de Antropologia e Etnologia, XXX (1-4): 151-173.

Vaquero Lastres, J. (1991-1992). Del análisis del emplazamiento al estudio de la distribución de túmulos en el NW. Brigantium, 7: 151-176. 
Final version: Carrero-Pazos, M., Bevan, A., Lake, M. 2019. The spatial structure of Galician megalithic landscapes (NW iberia): A case study from the Monte Penide region. Journal of Archaeological Science 108. https://doi.org/10.1016/j.jas.2019.05.004

Vaquero Lastres, J. (1993-1994). Galiñeiro, paso de lobos, novios y héroes. Sobre el emplazamiento de los túmulos del Noroeste. Cuadernos de Estudios Gallegos, XLI (106): 11-39.

Verhagen, P., Nuninger, L., Tourneux, F.P., Bertoncello, F., Jeneson, K. (2013). Introducing the human factor in predictive modelling: a work in progress. In: G. Earl, T. Sly, A. Chrysanthi, P. Murrieta-Flores, C. Papadopoulos, I. Romanowka, D. Wheatley (eds). Archaeology in the digital era. Papers from the $40^{\text {th }}$ annual conference of computer applications and quantitative methods in archaeology (CAA), Southampton, 26-29 March 2012. Amsterdam University Press, Amsterdam: 379-388.

Vilas Estévez, B. (2015). Estudio de las orientaciones y emplazamientos de los túmulos de la necrópolis de la Serra do Leboreiro en base a la Arqueología del Paisaje y la Arqueoastronomía. Santiago de Compostela: Universidade de Santiago de Compostela.

Villoch Vázquez, V. (1995). Monumentos y petroglifos: la construcción del espacio en las sociedades constructoras de túmulos del noroeste peninsular. Trabajos de Prehistoria, 52 (1): 39-55.

Villoch Vázquez, V. (2000). La configuración del espacio entre las sociedades constructoras de túmulos en Galicia: estudios de emplazamiento tumular. Santiago de Compostela: Universidade de Santiago de Compostela.

Wheatley, D. (1993). Going over old ground: GIS, archaeological theory and the act of perception. In: Andresen, J., Madsen, T., Scollar, I. (Eds), Computing the past. Computer applications and quantitative methods in archaeology. CAA92 (pp- 133-138). Aarhus University Press, Aarhus.

Wheatley, D. (1996). Between the lines: the role of GIS-based predictive modelling in the interpretation of extensive survey data. Analecta Praehistorica Leidensia 28: 275292.

Wheatley, D. (2004). Making space for an archaeology of place. Internet Archaeology 15. $10.11141 /$ ia.15.10

Wheatley, D. W., García Sanjuán, L., Murrieta Flores, P., Márquez Pérez, J. (2010). The megalithic phenomenon in Southern Spain: Approaching the landscape dimension. Oxford Journal of Archaeology 29 (4): 387-405. 
Final version: Carrero-Pazos, M., Bevan, A., Lake, M. 2019. The spatial structure of Galician megalithic landscapes (NW iberia): A case study from the Monte Penide region. Journal of Archaeological Science 108. https://doi.org/10.1016/j.jas.2019.05.004

Williams, J. T. (1993). Spatial autocorrelation and the Classic Maya collapse: one technique, one conclusion. Journal of Archaeological Science 20: 705-709. 
Final version: Carrero-Pazos, M., Bevan, A., Lake, M. 2019. The spatial structure of Galician megalithic landscapes (NW iberia): A case study from the Monte Penide region. Journal of Archaeological Science 108. https://doi.org/10.1016/j.jas.2019.05.004

Table 1. Variables of the locational model of the megalithic culture in Galicia as found in the literature (Carrero-Pazos 2017).

\begin{tabular}{|l|l|}
\hline Variable & Reference \\
\hline $\begin{array}{l}\text { Geology } \\
\text { (granite areas) }\end{array}$ & Leisner 1938; Bello Diéguez et al. 1982a, 1987 \\
\hline $\begin{array}{l}\text { Edaphology } \\
\text { (sites close to tillage } \\
\text { areas) }\end{array}$ & Criado Boado, Grajal Blanco 1981 \\
\hline $\begin{array}{l}\text { Altitude } \\
\text { (high elevation areas) }\end{array}$ & López Cuevillas 1959; Criado Boado 1988 \\
\hline $\begin{array}{l}\text { Topographic prominence } \\
\text { and visual impact }\end{array}$ & Criado Boado 1988 \\
\hline $\begin{array}{l}\text { Relation with transit } \\
\text { network }\end{array}$ & $\begin{array}{l}\text { Díaz Sanjurjo 1904; Castillo López 1927; López } \\
\text { al. 1982b, 1982c; Criado Boado, Vaquero Lastres 1991; } \\
\text { Vaquero Lastres 1991-1992, 1993-1994; Eguileta } \\
\text { Franco 1999; Gómez Vila 2005 }\end{array}$ \\
\hline $\begin{array}{l}\text { Visual impact and water } \\
\text { areas }\end{array}$ & $\begin{array}{l}\text { Vaquero Lastres 1990; Méndez Fernández 1998; Villoch } \\
\text { Vázquez 2000; Santos Estévez 2008 }\end{array}$ \\
\hline $\begin{array}{l}\text { Relation with other natural } \\
\text { features } \\
\text { archaeological remains } \\
\text { (petroglyphs) }\end{array}$ & $\begin{array}{l}\text { Filgueiras Rey, Rodríguez Fernández 1994; Villoch } \\
\text { Vázquez 1995, 2000; Santos Estévez et al., 1997 }\end{array}$ \\
\hline
\end{tabular}


Final version: Carrero-Pazos, M., Bevan, A., Lake, M. 2019. The spatial structure of Galician megalithic landscapes (NW iberia): A case study from the Monte Penide region. Journal of Archaeological Science 108.

https://doi.org/10.1016/j.jas.2019.05.004

Table 2. Previous results from multivariate logistic regression (Carrero Pazos, 2017: 489).

\begin{tabular}{|c|c|c|c|c|}
\hline \multicolumn{5}{|l|}{ A: Univariate logistic regression } \\
\hline \multicolumn{5}{|l|}{ Dependent variable: presence of sites } \\
\hline \multicolumn{2}{|l|}{ Covariable } & p value & \multicolumn{2}{|c|}{ Predictive value } \\
\hline \multicolumn{2}{|l|}{ Altitude } & 0 & \multicolumn{2}{|l|}{ Good } \\
\hline \multicolumn{2}{|l|}{ Geology } & 0.060 & \multicolumn{2}{|l|}{$\mathrm{Bad}$} \\
\hline \multicolumn{2}{|l|}{ Slope } & 0.271 & \multicolumn{2}{|l|}{$\mathrm{Bad}$} \\
\hline \multicolumn{2}{|l|}{ Landforms } & 0.010 & \multicolumn{2}{|l|}{ Good } \\
\hline \multicolumn{2}{|l|}{ Least cost path density } & $3.597 \mathrm{e}-10$ & \multicolumn{2}{|l|}{ Good } \\
\hline \multicolumn{2}{|l|}{ Cost of passage from potential routes } & 0.624 & \multicolumn{2}{|l|}{ Bad } \\
\hline \multicolumn{2}{|l|}{ Potential river network } & 0.001 & \multicolumn{2}{|l|}{ Good } \\
\hline \multicolumn{2}{|c|}{$\begin{array}{l}\text { Cost of passage from highly accumulated water } \\
\text { zones }\end{array}$} & $6.873 \mathrm{e}-08$ & \multicolumn{2}{|l|}{ Good } \\
\hline \multicolumn{2}{|c|}{ Visual prominence of landscape } & 0.610 & \multicolumn{2}{|l|}{$\mathrm{Bad}$} \\
\hline \multicolumn{2}{|l|}{ Topographic prominence $(100 \mathrm{~m})$} & 0.160 & \multicolumn{2}{|l|}{$\mathrm{Bad}$} \\
\hline \multicolumn{2}{|l|}{ Topographic prominence $(1000 \mathrm{~m})$} & $2.166 \mathrm{e}-10$ & \multicolumn{2}{|l|}{ Good } \\
\hline \multicolumn{2}{|l|}{ Wetlands } & 0.069 & \multicolumn{2}{|l|}{ Bad } \\
\hline \multicolumn{5}{|l|}{ B: Multivariate logistic regression } \\
\hline Coeficients & Estimate & Std.Error & $\begin{array}{l}\mathrm{Z} \\
\text { value }\end{array}$ & $\operatorname{Pr}(>|z|)$ \\
\hline (Intercept) & -3.420 & 0.646 & -5.287 & $\begin{array}{l}1.24 \mathrm{e}- \\
07\end{array}$ \\
\hline Altitude & 0.013 & 0.002 & 5.853 & $\begin{array}{l}4.83 \mathrm{e}- \\
09\end{array}$ \\
\hline Least cost path density & 0.065 & 0.017 & 3.806 & 0.000 \\
\hline Potential river network & -0.045 & 0.021 & -2.100 & 0.035 \\
\hline Cost of passage from water zones & -0.001 & 0.00 & -1.752 & 0.079 \\
\hline
\end{tabular}


Final version: Carrero-Pazos, M., Bevan, A., Lake, M. 2019. The spatial structure of Galician megalithic landscapes (NW iberia): A case study from the Monte Penide region. Journal of Archaeological Science 108.

https://doi.org/10.1016/j.jas.2019.05.004

Table 3. Results of the permutation tests on megalithic site sizes by cluster group.

\begin{tabular}{|c|c|c|c|c|c|c|c|}
\hline $\begin{array}{l}\text { Size- } \\
\text { Level }\end{array}$ & RankSums & RankMeans & IdealSums & IdealMeans & SimRank & MinSimRank & Pval \\
\hline 1 & 203.5 & 22.61111 & 45 & 5 & 5 & 18.5 & 0.005 \\
\hline 2 & 239.5 & 29.9375 & 108 & 13.5 & 25 & 22.5 & 0.025 \\
\hline 3 & 238 & 34 & 147 & 21 & 86.5 & 14.428571 & 0.0865 \\
\hline 4 & 121 & 24.2 & 135 & 27 & 25 & 7.8 & 0.025 \\
\hline 5 & 112 & 28 & 126 & 31.5 & 68 & 10 & 0.068 \\
\hline 6 & 128.5 & 32.125 & 142.5 & 35.625 & 148 & 10.125 & 0.148 \\
\hline 7 & 142 & 35.5 & 157.5 & 39.375 & 190.5 & 8.75 & 0.1905 \\
\hline 8 & 165 & 41.25 & 174 & 43.5 & 331.5 & 6.5 & 0.3315 \\
\hline 9 & 179.5 & 44.875 & 190 & 47.5 & 420 & 13 & 0.42 \\
\hline 10 & 109 & 36.33333 & 153 & 51 & 239 & 5.666667 & 0.239 \\
\hline 11 & 125.5 & 41.83333 & 162 & 54 & 376.5 & 4 & 0.3765 \\
\hline 12 & 147 & 49 & 171 & 57 & 532.5 & 7 & 0.5325 \\
\hline 13 & 165 & 55 & 180 & 60 & 693 & 9 & 0.693 \\
\hline 14 & 177 & 59 & 189 & 63 & 759.5 & 4.666667 & 0.7595 \\
\hline 15 & 187.5 & 62.5 & 198 & 66 & 856 & 4.666667 & 0.856 \\
\hline 16 & 196.5 & 65.5 & 207 & 69 & 860.5 & 5.666667 & 0.8605 \\
\hline 17 & 212 & 70.66667 & 216 & 72 & 928 & 7 & 0.928 \\
\hline 18 & 225 & 75 & 225 & 75 & 958 & 6.666667 & 0.958 \\
\hline 19 & 143 & 71.5 & 155 & 77.5 & 883 & 2.5 & 0.883 \\
\hline 20 & 150 & 75 & 159 & 79.5 & 914.5 & 2.5 & 0.9145 \\
\hline 21 & 152 & 76 & 163 & 81.5 & 927.5 & 2 & 0.9275 \\
\hline 22 & 154 & 77 & 167 & 83.5 & 923.5 & 4 & 0.9235 \\
\hline 23 & 65 & 65 & 85.5 & 85.5 & 680 & 1 & 0.68 \\
\hline 24 & 68 & 68 & 85.5 & 85.5 & 692.5 & 1 & 0.6925 \\
\hline 25 & 70 & 70 & 87 & 87 & 748 & 1 & 0.748 \\
\hline 26 & 72 & 72 & 88 & 88 & 762 & 1 & 0.762 \\
\hline 27 & 73 & 73 & 90 & 90 & 759 & 1 & 0.759 \\
\hline 28 & 83 & 83 & 90 & 90 & 893 & 1 & 0.893 \\
\hline 29 & 87 & 87 & 90 & 90 & 915.5 & 1 & 0.9155 \\
\hline 30 & 88 & 88 & 92.5 & 92.5 & 928 & 1 & 0.928 \\
\hline 31 & 92.5 & 92.5 & 92.5 & 92.5 & 984 & 1 & 0.984 \\
\hline 32 & 94 & 94 & 94 & 94 & 996.5 & 1 & 0.9965 \\
\hline
\end{tabular}


Final version: Carrero-Pazos, M., Bevan, A., Lake, M. 2019. The spatial structure of Galician megalithic landscapes (NW iberia): A case study from the Monte Penide region. Journal of Archaeological Science 108.

https://doi.org/10.1016/j.jas.2019.05.004

Figure 1. The study area in Galicia (NW Iberia), overlain on a shaded relief model.

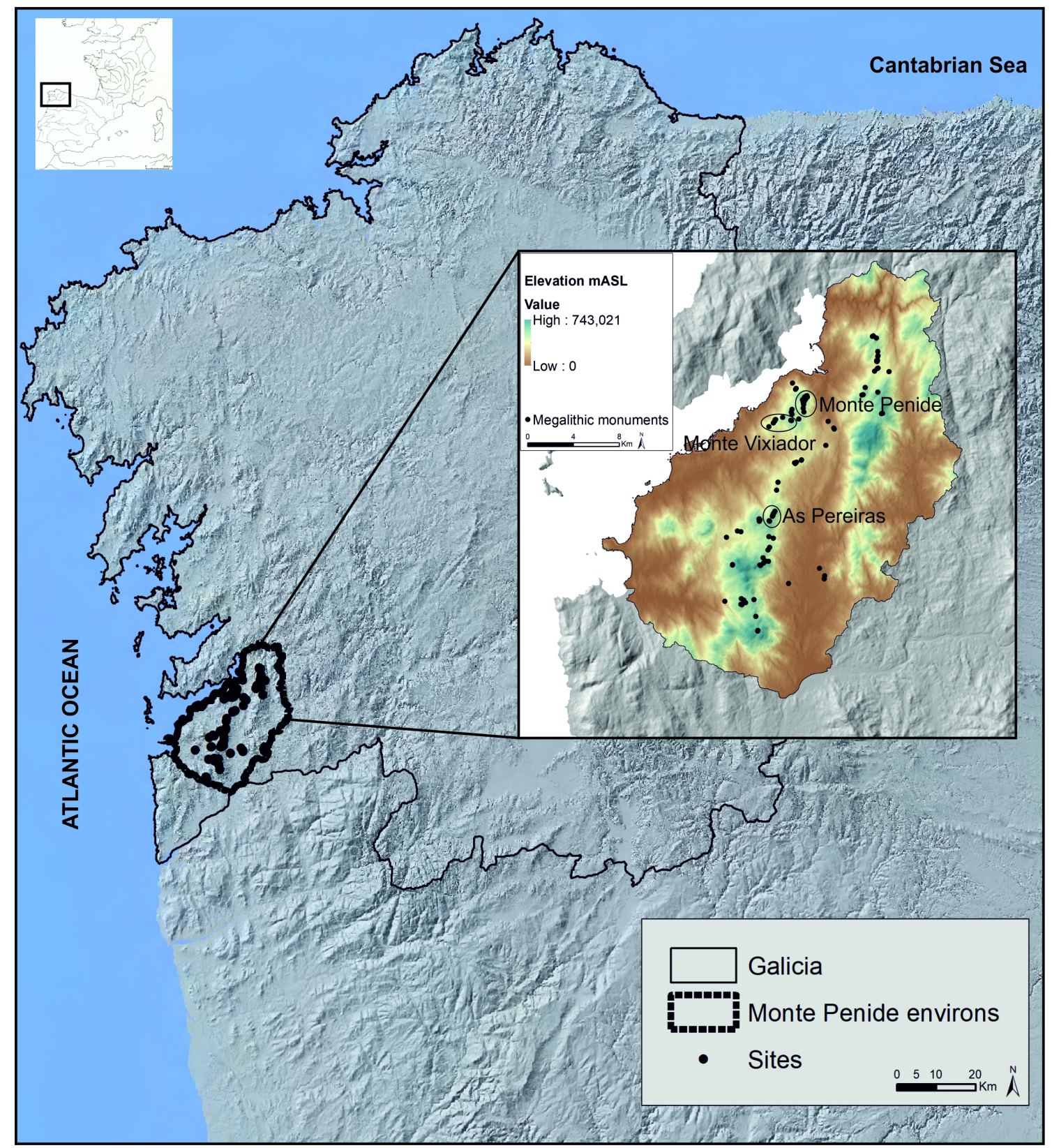


Final version: Carrero-Pazos, M., Bevan, A., Lake, M. 2019. The spatial structure of Galician megalithic landscapes (NW iberia): A case study from the Monte Penide region. Journal of Archaeological Science 108. https://doi.org/10.1016/j.jas.2019.05.004

Figure 2. A: Current photograph from a megalithic mound in Monte Penide. B: Field plans of the excavations carried out by C. Mergelina (1936) in some of the monuments.

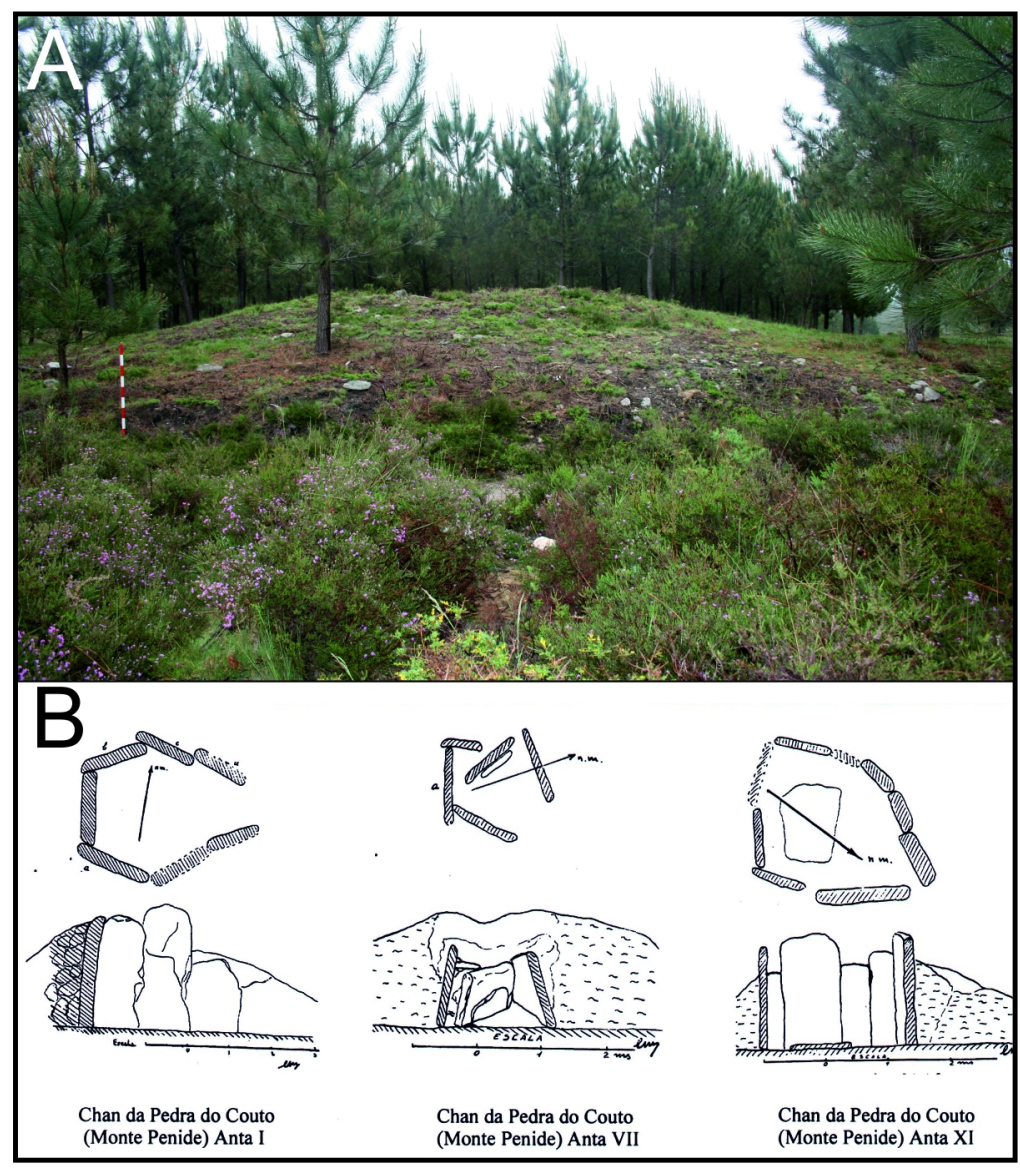


Final version: Carrero-Pazos, M., Bevan, A., Lake, M. 2019. The spatial structure of Galician megalithic landscapes (NW iberia): A case study from the Monte Penide region. Journal of Archaeological Science 108. https://doi.org/10.1016/j.jas.2019.05.004

Figure 3. A: Watershed boundaries shown on top of an elevation model (the latter a first order covariate). B: A second covariate constructed by calculating the distance to watershed edges (excluding coastlines and with certain watersheds merged so that only basins with sea outlets remain). C: Megalith site intensity as a function of terrain elevation. D: Megalith site intensity as a function of watershed distance (solid lines show function estimate while grey shading is pointwise $95 \%$ confidence envelope). E: The predicted log intensity of megalithic sites in the Monte Penide as constructed via logistic regression. 
Final version: Carrero-Pazos, M., Bevan, A., Lake, M. 2019. The spatial structure of Galician megalithic landscapes (NW iberia): A case study from the Monte Penide region. Journal of Archaeological Science 108.

https://doi.org/10.1016/j.jas.2019.05.004

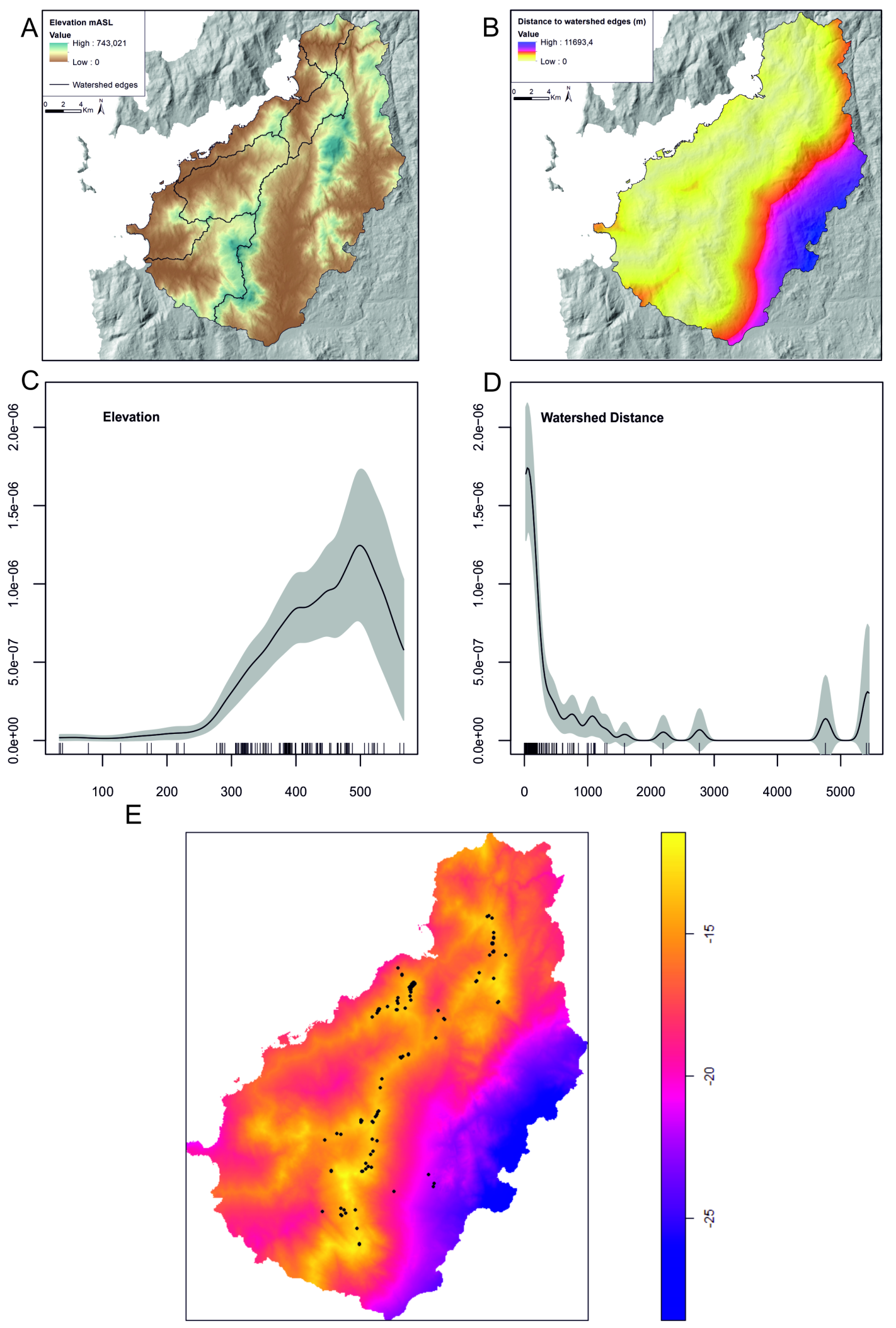


Final version: Carrero-Pazos, M., Bevan, A., Lake, M. 2019. The spatial structure of Galician megalithic landscapes (NW iberia): A case study from the Monte Penide region. Journal of Archaeological Science 108. https://doi.org/10.1016/j.jas.2019.05.004

Figure 4. Approaches to site distance and confidence. A: Pair correlation function with a 95\% envelope from wholly random Poisson process. B: Pair correlation function of the observed sites with a 95\% envelope conditioned on the first-order covariates model. C: Pair correlation function with a $95 \%$ envelope also conditioned on both the firstorder covariates and a second-order, area-interaction model $(\mathrm{r}=1500 \mathrm{~m})$.
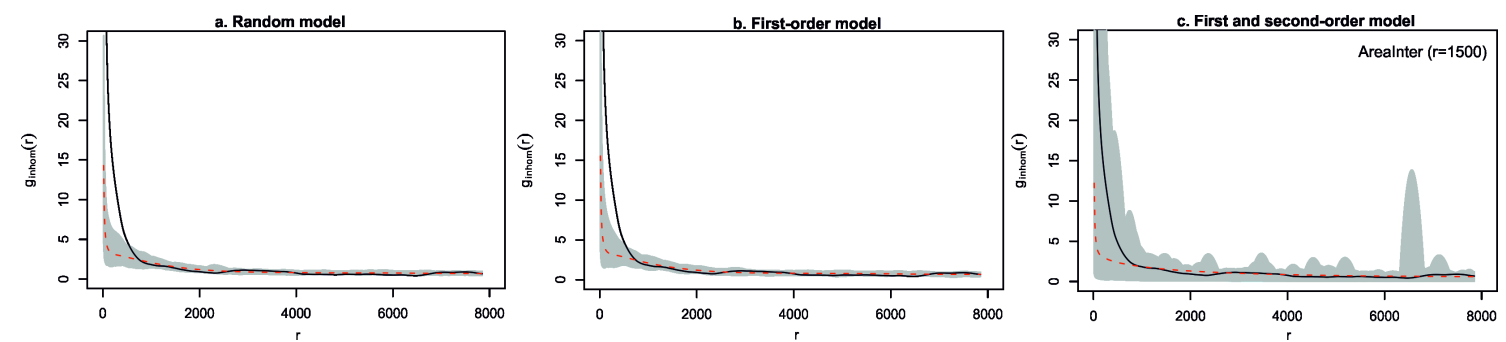
Final version: Carrero-Pazos, M., Bevan, A., Lake, M. 2019. The spatial structure of Galician megalithic landscapes (NW iberia): A case study from the Monte Penide region. Journal of Archaeological Science 108. https://doi.org/10.1016/j.jas.2019.05.004

Figure 5. A: Results of the mark correlation function for mound sizes/volumes. B: Results of dbscan grouping analysis, showing possible groups of sites with a territorial meaning.
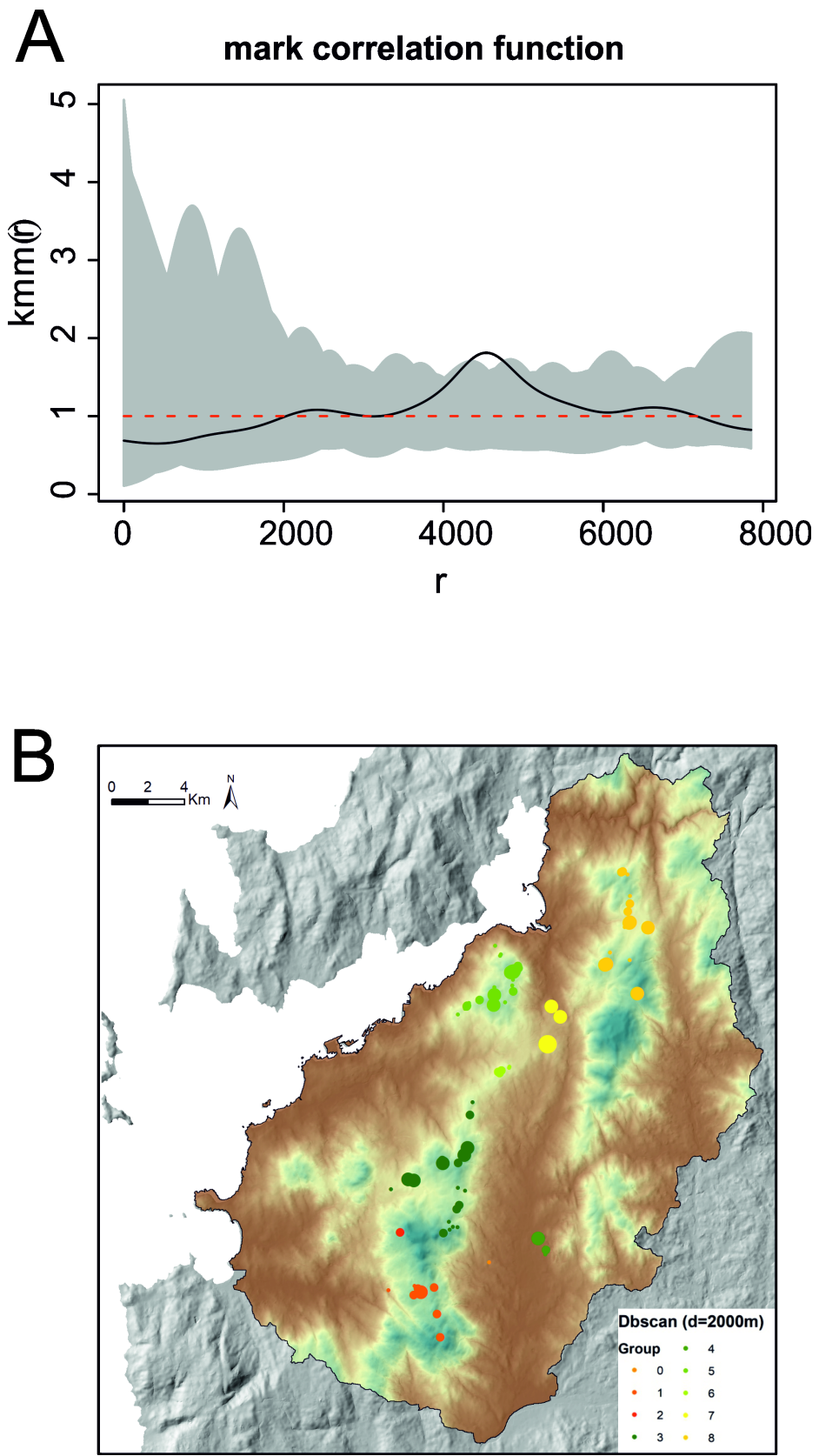